\title{
Phenomenon of Social Climbing in the Younger Generation in Malang City Hotels
}

\author{
$1^{\text {st }}$ Panca Kumala Dewi \\ Faculty of Social Sciences \\ Universitas Negeri Malang \\ Malang, Indonesia \\ pancadewi445@gmail.com \\ $2^{\text {nd }}$ Mohammad R.F Qowim \\ Faculty of Social Sciences \\ Universitas Negeri Malang \\ Malang, Indonesia
}

\author{
$3^{\text {rd }}$ Sania Aristantia \\ Faculty of Social Sciences \\ Universitas Negeri Malang \\ Malang, Indonesia
}

$4^{\text {th }}$ Mufidatul Maulidia

Faculty of Social Sciences

Universitas Negeri Malang

Malang, Indonesia

\author{
$5^{\text {th }}$ Alan Sigit Fibrianto \\ Faculty of Social Sciences \\ Universitas Negeri Malang \\ Malang, Indonesia \\ alan.sigit.fis@um.ac.id
}

\begin{abstract}
Today's young generation loves hunting to get long-term tourist fun through social networking sites. At present the hotel is a tourist destination for generation $Z$ to travel by aiming to improve Social Climber or commonly called social climber. The formulation of the problem taken is: "What is meant by social climbing, why is generation $Z$ doing social climbing in hotels and how the impact of the phenomenon of social climber on generation $Z$ in Malang City". This study uses a qualitative descriptive method that intends to provide an overview and description of tourism patterns seeking pleasure in the $\mathrm{Z}$ generation in doing social climber on social networking sites. The results showed that tourism is not only to get out of the routine and get pleasure but tourism has another function, namely the existence of continuous pleasure, so that in obtaining the pleasure of traveling, the most important thing is not when traveling in the hotel but the pleasure obtained after they take photos and stock photos that make traveling pleasure feel longer.
\end{abstract}

\section{Keywords: social climbing, $Z$ generation, hotel tour, existence}

\section{INTRODUCTION}

The current young generation tend to already have a particular interest and passion as it does on appearance, they strive to be able to look attractive for attractiveness and recognition for those who see it. According to Kernan [1] "Self Appearance especially in the presence of his friends is a strong hint of interest in socializing the young generation".

In terms of the younger generation are often eager to show all abilities himself to a broad audience. [2] suggests that the younger generation has an excessive appreciation against their own lives and will continue to feel envy to others that are more successful, smarter and prettier than her.

Technological development has brought mankind much to creating new forms of socializing through technology innovations such as social networking as one means to communicate effectively. Social media is also very useful in human life: with their daily activities in a show of social networking through photos or videos that are uploaded. Problems concerning the current younger generation has always been associated with social networking, they will constantly communicate through social media often spend time just for social media. This is due to a lot of young people nowadays tend to want to get attention and build the image of the present generation. Whereas, social media as a product of technology also has some weaknesses. There are many risks faced by its users, including the insecurity of personal data [3]. However, if users can make good use of technology, they will get the benefit 
hotel can attract visitors to simply perpetuate the the moment without having to stay at the hotel.

On the discussion of research focusing on four issues. The phenomenon of social climbing, climbing the social phenomenon of problems often occur in the younger generation, chose the hotel as a tourist spot on the younger generation, the impact of the phenomenon of social climbing towards the younger generation.

\section{LITERATURE REVIEW}

As for the researchers chose to take this focus because the researchers found that there had been many such social climbing phenomenon occurred against the young generations in the poor Kingdom in particular about the phenomena that occur in the hotel as well as the resort which had been made by their object as a medium to conduct social climbing. In addition researchers also want to fine-tune the results of previous research as has been done by the Permatasari [9] in his Thesis entitled "Social Climber Phenomenon among college students (the study of Phenomenology on students in Surakarta)" which in the thesis he discusses about how perpetrators of student social climber in Surakarta convey their social status through the indicated symbols such as underwear model who is currently a trend or other accessories as a means of conveying information by means of posting their activities on account instagram.

In addition to the five outcomes of research that has been done the researchers did not find any focus that deals with the phenomenon of the illegal activities of the young generation which they want to show the existence of himself by way of a visit to a hotel or resort in the region of malang raya, to do a social climbing or better known as the Social Climber. In order to examine the phenomenon of researchers using several theories, one of which, namely the use of the theory of the concept of Self Concerning the role of identity according to McCall and Simmon [10], which in the theory is to explain about the importance of a specific identity that is also influenced by the relative level of individual commitment and investment in it as well as the identity of the individual can also find satisfaction gained from carrying out the role that [11]. When linked with the phenomenon of social climbing is very suitable because the younger generation for the sake of carrying out her role willingly spend money to come to a hotel or resort only to just play and taking pictures of herself against the background of the photographs that later would they upload on their social media account and the posting of their hope of getting feedback and response from the others and looked at herself as an object according to the the other person's perspective and from where that person will obtain the identity of the people who viewed the postings though that identity only last a while.

In addition to reviewing this case researchers also use Dramaturgi Theory as a means to examine the phenomenon of social climbing cases conducted by the younger generation in 
Social media could contribute to a ' narcissistic ' millennial particular is currently residing in Malang areas. [12] Erving Goffman is sociologist Canada who first conceived the theory of which he is a figure of interactionist sect members at once symbolic of Chicago. In the theory, Goffman argues that the world is a stage [13], as described in his work entitled La Presentation de Soi (self presentation) that assume individuals in social interactions as an actor who holds the roles and social relationships as a representation that is subject to a fixed rule, as well as actor or individual making an impression of reality to their neighbour in order to convince a picture or image of yan wanted to give to others by way of adapting the appearance through the roles and the drama in everyday life [14].

Explanation of the theory is strongly associated with social climbing phenomenon that occurs in younger generation nowadays, where they compete to ride in the stage in order to gain an impression of the reality of the neighbor with How to come and tour the hotel-the hotel of the younger generation that will gain high social identity which it certainly will affect the image of the given others to him. It is surely now familiar due to the current young generation prefers the impression their reality from the virtual world and they hope to have an assessment of their social statu is more real than the real world or in the the term was known by the Hyperreality.

In a news story that reported by from 4 September 2015 Kapoww who made news as follows, self-serving, greedy, want to win on its own, and would like to note, that's the assumption regarding the generation of millennial doctrines which are then summarized in one definition: narcissist.

According to the survey of IRI [15], 90 percent of respondents defined success by being a good friend, i.e. the positive relationship in the work as well as personal. While 68 percent associate success with work. Compared with 56 percent for generation $X$ (the birth of the 70 's and 80 ' 60s) and a generation of baby boomers (the birth of 60-70s), this looks like it is not a bad thing.

The millennial generation is also often considered to be always wanted to be noticed and appreciated. Stemmed from a habit that is applied by the previous generation. In the reference 'Freedom to Learn', the famous psychologist Carl Rogers [16] suggested that the company could improve the confidence of their employees. Any school pupils are supported in order to be more spontaneous and free. The moral assessment of ' good and bad ' else applied, and people are required to be more critical.

The impact of these problems many companies boast of their employees for the sake of maintaining the reputation and workers. One of the most searched keyword in recent years is ' employee engagement '-employee engagement. This is not a bad thing. When generation $\mathrm{X}$ and the baby boomers just sitting at the table waiting for the promotion of the millennial generation, the boss wants to do business so that their work is appreciated. This is considered a form of narcissism, though indeed a form of self development efforts. child [17]. Though perhaps this is not a bad thing forever. Through the media like Instagram, people have the opportunity to become the center of attention, both from the achievement, appearance, or sensation [18]. This often triggers the taste not to be outdone, so that the millennial generation children vying showcased all the good side of their life [19].

\section{METHOD}

In this study researchers using qualitative methods are purely descriptive that aims to collect data and explains in detail about the research that has been studied by researchers [20]. The location of this research is Maxone in Malang, this location was chosen because of the many tourists who visit especially the teenagers who just been to take pictures because the place instagramable for them. Data collection techniques researchers using the technique of observation and interviews to the visitors the MaxOne hotel was a teenager. Technique of data analysis used in this study refers to the concept of the thought expressed simultaneously and three events namely, (1) the reduction of data, (2) presentation of data, (3) the withdrawal of the conclusion. The validity of the data using the triangulation of data between answer one informant with other informants.

\section{RESULTS AND DISCUSSION}

\section{A. The Tendency of Younger Generations in the City of Malang}

The younger generation in the city of Malang on the times now has a tendency of utilizing leisure time by visiting places that are considered attractive by young people. Places that are considered interesting at this point that is a unique place to have a nice view. Young people today have a tendency to spend free time with hanging out and vacations to places that are unique, modern, convenient to visit. By looking at the trend of young children who love to play or hang out it that makes places to hang out in the city of malang is thriving, since year 2015. With a variety of young children making hangout today prefer to spend the spare time to have fun in places nearby and recomended to visit.

The fun here is defined as tourism that means an activity that is havin - happy (leisure) which is characterized by spending money or doing the consumerist nature of activities [22]. Often the people doing the tour aims to release tired, and often to relieve tired someone in need of a tour is not disinclined to spend a lot of money, to get pleasure when travelling.

The tourist (tourist) Word referring to a. In general the tourists became part of the traveller or referred to as visitor. To be referred to as a tourist, a person must be a traveller or a visitor [23]. In the English-United Kingdom, people who travel are called traveller. While those who travel for tourism destination is called the tourist. Whereas in the Tourism Act No. 9 of the by Miles and Huberman [21] that an analysis done 
year 2000 says that the tourists are defined as people doing activities.

Talk about the current tour is closely associated with a penchant for photos of generation Z, in the Division theory of generation of the most fond of doing the Hunting or on call by taking a photo with an interesting object that is generation $\mathrm{Z}$ is the generation born in the year 1994 and above under the year 2004 , the generation $\mathrm{Z}$ is often brought up in the digital age by using technologies that are more advanced and modern [24].

Generation $\mathrm{Z}$ assume that photos are a necessity to increase in popularity, it is very closely related to tourist attractions strongly support background photo that can determine the outcome of the photo can be good or not. With the photo as the need to make the generation $\mathrm{Z}$ are not loose his life from such a technology gadget, internet, and social media.

Generation $\mathrm{Z}$ is a very selfish generation popularity: with the large number of followers and many likes in their social media account, generation $\mathrm{Z}$ this is a transition from generation $\mathrm{Y}$ where technology is developing at birth year 1995-2010 [25]. To get the popularity of generation $\mathrm{Z}$ is always up to date on social media by always uploaded photos with the span of time that's not long. Because to feedback from followers who both gave positive comments and likes making generation $\mathrm{Z}$ happy to up to date so it is the background behind the generation $\mathrm{Z}$ hobby traveling to travel while hunting photos.

The younger generation now is fond of travelling which aims not only to obtain pleasure while visiting but also to get a good photo. It is also described by informants that tours that make entertainment while existence, take a picture, a place to create assembled but more create people hunting spot photos from on the tour and enjoy the beauty of to in a post on the social accounts the media. It is widely found in the sights that people visiting the tourist attractions more busy looking for a great photo spot to capture the moment.

Based on the foregoing shows that the existence of a tendency for self-existence tour, tour of the function which aims at eliminating fatigue is now a need for up to date on social media. So at the moment it can to increase the popularity of the tour through the results of a nice photo. This makes the tour become a necessity inherent in young children in gaining popularity.

Generation $\mathrm{Z}$ has terms like present or well-known meaning hits, the latest, is being discussed as a trending topic among the generation $\mathrm{Z}$, about a popular photo spot at the moment. Generation $\mathrm{Z}$ is also a generation that love to take the time to do a spot of hunting activities photos, generation $\mathrm{Z}$ because it likes to exist they would rather work with the select tourist attractions that are closer to their destination where most of it is selfie and hang out in the cafe, thematic tourist attractions and hotels.
From year 2017-2018 found the phenomenon of children who visit and do tours to hotels because the hotel touted as the present because many have sprung up on the veranda at the social media generation $\mathrm{Z}$ are many photos uploaded by tagar marking their pictures when in hotels that are currently on the visit in the city of Malang.

\section{B. Hotel as a Tourist Destination}

The hotel as a tourist destination Hotel derives from the hostel from latin, namely hostesses. Public buildings have been called in the 17 th century its meaning as a shelter made of entrants or as a provider of building cabins and meals to the public. The definition of the hotel is the type of accommodation or use all or part of the building to provide lodging, eating and drinking as well as other services for commercially-run public [26].

According to the definition in general hotel is a place that provides lodging to the public, but at the moment the generation $\mathrm{Z}$ considers hotel not just as a place to stay but there are other functions from the hotel are:

- Generation of $\mathrm{Z}$ to the hotel aim to swim, because according to their swim in the hotel's private, quiet, and made it possible to spot the photo.

- The Generation $\mathrm{Z}$ usually chose the hotel as a place for a photo album of memories together with classmates, because according to their view of the hotel is great for is enshrined.

- Hotels are usually created to celebrate anniversary poems people who lose, they chose the hotel because the hotel usually give facilities live music so that more supportive atmosphere of the beloved couples are in love.

The phenomenon can be seen in a wide range of social media that use the hastag hotels malang. The more the hastag which marked a person who visited the hotel, usually making generation $\mathrm{Z}$ are interested would like to see the hotel and view hunting photos. It is on show with photos that were hits or popular among generation $\mathrm{Z}$ i.e. photo at hotel MaxOne precisely in the pool area which has a beautiful view and instagramable.

The hotel is currently a popular tourist place for generation $\mathrm{Z}$ because it offers a beautiful place, exclusion and modern. The hotel synonymous with opulence and only those interested parties who stay at the hotel. But now it also as a place of tourism hunting photos, average - average hotel in Malang ever visit the generation $\mathrm{Z}$ is Maxone, Hotel Sulawah, Hotel Ubud, ijenswites etc. the reason they choose hotels because the photo spot in the pool area instagramable.

The hotel during this time in attracting tourism to simply visit usually they do live music events, received orders setting place according the wishes of the customer, provides the 
package's diner, a package of dessert, and promo rent rooms for visitors who want to visit or a longer stay.

Most of them to the hotel for a swim if they want to swim typically go to the reception of the hotel or to the hotel restaurant to buy something and going to the pool for swimming. If they only want to visit for a photo in the hotel they may go directly to the top floor without dimintain payments, it is not for all hotels due to the policy of each hotel is different if the hotel could swim if not Maxone as you wish to the 7th floor for selfie or just enjoy the view.

\section{Photo at the Hotel as an Attempt of Social Climbing}

Social climbing is a free translation of the term millennial doctrines i.e. social climber who could also be in define the man who craves attention. Social climbers can be described with a person who likes the popularity of one way the social climbers do climb social with friends with the popular people and also upload images with spot photos which he becomes a pleasure to take pictures with the background such as going to the hotel just to take pictures only for existence in social media.

A person who does social climbing it mostly because they want to be a child or a regular on call hits the children present. They interpret the older hits with the definition of someone who wants to become famous through social media by uploading photos on a place that many are talking about others or called with a boom. The activities of the child hits according to them is to do traveling to places that have a great photo spot, then they upload photos to social media like Instagram, create a story on Instagram and to a variety of social media accounts others. They considered that the activities which often they do like traveling photography that makes them increasingly appreciated and recognized others, many add friends from follower on instagram, much like the photos they post.

A person who does social climbing it mostly because they want to be a child or a regular on call hits the children present. They interpret the older hits with the definition of someone who wants to become famous through social media by uploading photos on a place that many are talking about others or called with a boom. The activities of the child hits according to them is to do traveling to places that have a great photo spot, then they upload photos to social media like Instagram, create a story on Instagram and to a variety of social media accounts others. They considered that the activities which often they do like traveling photography that makes them increasingly appreciated and recognized others, many add friends from follower on instagram, much like the photos they post.

Social climbing is important for someone who wants to have an existence and pleasure from the recognition of others. But not all agree with regard to social climbing was important because hunting photos and travelling has become a hobby of generation $\mathrm{Z}$ so that they assume a social climbing is not an important, but indirectly they admit that they do social climbing. Because to obtain satisfaction in the results of their photo willingly looking for places that are instagramable although the place of the said place is expensive to create a spot on the photo. Take the example for all sightseeing at Hotel Maxone, with the theme "Semeru" meaning sunset maxone exclamation, the costs of which they should remove the start from $\mathrm{Rp} 50,000$, if you want to enjoy some kind of dessert bowl smoothies nett price of Rp 35,000 this stated purpose the hotel is still cheaper than other hotels for all swim could reach Rp 100,000, with so not wrong when someone who is hanging out in the Hotel's more classy look so it looks different social status.

The hobby of hunting by doing a lot of traveling to the places that are instagramable according to them apart can get fame at social media they are also getting a lot of new things like socializing with all walks of life, many friends who have links from a variety of backgrounds, always update with places that are often discussed and widely visited or called hits and no less important they feel they have a point of satisfaction when the photo results in the get a good deal.

Advances in technology also supports the person doing the social climbing in places that are instagramable because of the camera also belongs to cheap borrowing makes them feel nothing less if travelling without doing the photos. Because they assume good follower with respond much like in every posting photos. Make them want to do photo hunting to get intense pleasure through like follower given up posting photos that public good. Indirectly they feel on notice and recognized through like photos or comments that are compliments.

\section{The Impact of Social Climbing}

\section{1) The Positive Impact}

Being a child present in the present era it is a pleasure and a hobby or job opportunities which could be profitable. Often children who present many follower and like the photos up to hundreds or even tens of thousands can bring business opportunities, or services promote endorsement.

So someone who is very present in social media is very likely to become selebgram, so often the younger generation wants to be older hits many of which mimic the lifestyles of selebgram that time of her life spent on the streets, treveling to the places which is instagramable.

\section{2) The Negative Impact}

When the follower is growing a person will surely think of innovation or what content should always be updated on his post. So someone feel to have the requirement to always update for the sake of pleasure myself because already in appreciation by follower through like and always updates the following story on Instagram. So it was that made the famous $\mathrm{Z}$ generation narcissist consumerist in nature by imitating the lifestyle of a selebgram hobby, follow the path, money and keep your image by doing Imaging to classy places. 
(Eds.), Hospitality and Tourism: Synergizing creativity and innovation in research (pp. 471-474). Croydon, Great Britain: Taylor \& Francis Group.

[9] Permatasari, Dewi. (2017). Fenomena Social Climber di Kalangan Mahasiswa (Studi Fenomenologi pada Mahasiswa di Surakarta). Institut Agama Islam Negeri Surakarta.

[10] McCall, G. J., \& Simmons, J. L. (Eds). 1969. Issues In Participant Observation: A Text and Reader. Reading: MA: Addison-Wesley.

[11] Johnson, Paul. (1986). Teori Sosiologi Klasik dan Modern Jilid 2. Jakarta: PT. Gramedia.

The definition of 'tour' is out of rutinity and get the joyful from it. However, they get the joyful from the pictures they post on social media and having stock photo that make the joyful more long-lasting. The definition of 'tour' is out of rutinity and get the joyful from it. However, they get the joyful from the pictures they post on social media and having stock photo that make the joyful more long-lasting.

\section{REFERENCES}

[1] Santrock, J. W. (1980). Psikologi Perkembangan. Jakarta: Erlangga.

[2] Halgin, R.P \& Whitbourne, S.K. 2010. Psikologi Abnormal (Perspektif Klinis Pada Gangguan Psikologis).Jakarta : Salemba Humanika.

[3] Yuniar, A. D., \& Fibrianto, A. S. (2019, June). Big Data Dilemma: Technology Advance Versus Privacy Violation. In 1st International Conference on Social Knowledge Sciences and Education (ICSKSE 2018). Atlantis Press.

[4] FIBRIANTO, ALAN SIGIT. Praktik Sosial Komunitas Difabel 'Difa City Tour dan Transport'dalam Proses Hubungan Industrial (Studi Kasus pada Perusahaan Industri Jasa Kreatif Ojek Online Kalangan Difabilitas Berbasis Komunitas di Yogyakarta). Diss. Universitas Sebelas Maret, 2018.

[5] Fibrianto, A., Yuniar, A., \& Irawan, M. (2018, August). 20. Rationality of Utilization and the Making of Virtual Democracy Using Smartphone Applications. In 5th International Conference on Social and Political Sciences (IcoSaPS 2018). Atlantis Press.

[6] Fibrianto, A. S., \& Yuniar, A. D. (2019, June). Technological Development and its Impact on Community Social Behavior. In 1st International Conference on Social Knowledge Sciences and Education (ICSKSE 2018). Atlantis Press.

[7] Nasrullah, Rulli. 2016. Media Sosial:Perspektif Komunikasi, Budaya, dan Sosioteknologi. Bandung:Simbiosa Rekatama Media.

[8] Hanan, H. \& Putit, N. (2014). Express marketing of tourism destination using Instagram in social media networking. In Norzuwana Sumarjan, Mohd Salehudin Mohd Zahari, Salled Mohd Radzi, Zurinawati Mohi, Mohd Hafiz Mohd hanafiah, Mohd Faeez Saiful Bakhtiar \& AtinahZainal
[12] Ritzer, George, dan Goodman, Douglas J. (2008). Teori Sosiologi dari Teori Klasik sampai Perkembangan Mutakhir Teori Sosial Postmodern (Penerjemah: Nurhadi). Yogyakarta: Kreasi Wacana.

[13] Syam, Abdi Mubarak. (2014). Dramaturgi: Media Sosial sebagai Panggung Presentasi Diri. Tesis Magister, Universitas Indonesia.

[14] Arisandi, Herman. (2015). Buku Pintar Pemikiran Tokoh-Tokoh Sosiologi. Yogyakarta: IRCiSoD.

[15] Intermedia Research Indonesia (2018)

[16] Rogers, Carl. 1959. "A theory of therapy, personality and interpersonal relationships as developed in the client-centered framework.". in (Ed.) S. Koch.Psychology: A study of a science. Vol. 3: Formulations of the person and the social context.New York: McGraw Hill.

[17] Engkus, Hikmat, dan Saminnurrahmat, Karso. (2017). Perilaku Narsis pada Media Sosial di Kalangan Remaja dan Upaya Penanggulangannya. Universitas Islam Negeri Sunan Gunung Djati. https://www.researchgate.net/publication/322229834

[18] https://www.liputan6.com/global/read/2309368/millennial-generasinarsis-gila-gadget-dan manja

[19] Putra, Yanuar Surya. (2017). Review: Teori Perbedaan Generasi. STIE AMA Salatiga. https://jurnal.stieama.ac.id/index.php/ama/article/view File/142/133

[20] Moleong, L. (2015). Metode Penelitian Kualitatif. Bandung: PT. Remaja Rosdakarya.

[21] DeVito A. Joseph. (2010). KOMUNIKASI ANTARMANUSIA Edisi Kelima. Jakarta: Karisma Publishing.

[22] Heriawan, Rusman. (2004). Peranan dan Dampak Pariwisata pada Perekonomian Indonesia: Suatu Pendekatan Model I-O dan SAM. Disertasi Doktoral, Institut Pertanian Bogor.

[23] Pitana, I. G., dan Diarta, I Ketut Surya. (2009). Pengantar Ilmu Pariwisata.

[24] Hellen Chou Pratama. (2012). Cyber Smart Parenting. Bandung: PT. Visi Anugerah Indonesia.

[25] Faiza, Arum, dan Firda, Sabila J. (2018). Arus Metamorfosa Milenial. Kendal: Ernest.

[26] Ismayanti. (2009). Pengantar Pariwisata. Jakarta: PT. Gramedia Widiasarana Indonesia. Yogyakarta: L-Kis. 